\title{
Konseling Eklektik Islami untuk Mengubah Konsep Diri Waria
}

\author{
Sutarto, Syafriyadin, Jumira Warlizasusi
}

\author{
IAIN Curup \\ soetartoo74@gmail.com
}

Submitted: 2019-03-17, revised: 2019-03-17, accepted: 2019-06-25

\begin{abstract}
Abstark: This study aims to reveal the self-concept of transvestites, provide assistance for eclectic Islamic counseling services and know the effectiveness of Islamic eclectic counseling to change the self-concept of transvestites. The type of research used is Participatory Action Resarch (PAR) with four stages of implementation, namely planning, action, assessment and follow-up. The results of the study indicate that transvestites in understanding their own concepts can be grouped into two, namely; First, transvestites who see themselves as women and that are already destiny. Second, transvestites who see themselves as men but look like women. Transvestites assume that the community views itself as a woman, must appear like a woman and the community sees one eye towards her. Of the 18 transgender people who participated in the counseling process 1 person was determined to really want to change his appearance. 10 people are aware that they are men and their appearance should be like men but do not know when they will change their appearance and 7 people still understand themselves as women and must appear as a woman.
\end{abstract}

Keywords: Islamic Eclectic Counseling; Self Concept of Transvestites

\begin{abstract}
Abstark: Penelitian ini bertujuan untuk mengungkapkan konsep diri waria, memberikan bantuan pelayanan konseling eklektik Islami dan mengetahui tingkat keefektifan konseling eklektik Islami untuk mengubah konsep diri waria. Jenis penelitian yang digunakan adalah Participatory Action Resarch (PAR) dengan empat tahap pelaksanaan, yaitu perencanaan, tindakan, penilaian dan tindak lanjut. Hasil penelitian menunjukkan bahwa waria dalam memahami konsep dirinya dapat dikelompokkan menjadi dua, yaitu: Pertama, waria yang memandang dirinya sebagai seorang perempuan dan itu sudah merupakan takdir. Kedua, waria yang memandang dirinya sebagai seorang laki-laki namun penampilannya seperti perempuan. Waria beranggapan bahwa masyarakat memandang dirinya sebagai seorang perempuan, harus tampil seperti perempuan dan masyarakat memandang sebelah mata terhadap dirinya. Dari 18 orang waria yang mengikuti proses konseling 1 orang bertekad benar-benar ingin merubah penampilannya. 10 orang sadar bahwa dirinya adalah laki-laki dan penampilanya seharusnya seperti laki-laki namun belum tahu kapan akan merubah penampilannya dan 7 orang masih tetap memahami dirinya sebagai perempuan dan harus tampil sebagai mana layaknya perempuan.
\end{abstract}

Kata kunci: Konseling Eklektik Islami; Konsep Diri Waria

\section{Pendahuluan}

Dalam kehidupan masyarakat biasanya dikenal dua jenis identitas, yaitu laki-laki dan perempuan. Keduanya harus menampilkan jati dirinya sesuai dengan karakteristiknya masing-masing. Laki-laki idealnya menampilkan sifat maskulin dan perempuan menampilkan sifat feminim. Namun ada sebagian orang yang menampilkan jati dirinya tidak sesuai dengan jenis kelaminnya, diantaranya adalah waria (wanita pria), atau wadam (hawa adam) atau oleh masyarakat awam dikenal dengan istilah banci. Waria pada dasarnya adalah laki-laki normal, namun secara psikologi merasakan dirinya sebagai wanita. Akibatnya adalah sikap dan perilaku yang ditampilkan dalam kehidupan sehari-hari seperti layaknya perempuan, mulai cara bicara, cara berjalan, cara berpakaian dan cara berpenampilan seperti layaknya seorang perempuan. Apabila seorang individu menampilkan jati dirinya tidak sesuai dengan identitasnya, maka secara sosial dan teologis dianggap sebagai suatu penyimpangan atau abnormalitas orientasi identitas gender (Koeswinarno, 2005). Dalam DSM V (Diagnostic and Statistical Manual of Mental Dosiders, Fifth Edition), waria digolongkan sebagai individu yang mengalami gangguan yang diistilahkan dengan Gender Dysphoria, yaitu ketidakpuasan individu baik secara kognitif maupun afektif terhadap jenis kelaminnya. 
Di provinsi Bengkulu, khusunya di Kabupaten Lebong jumlah waria sekitar 400 orang, yang terbanyak adalah di desa Ujung Tanjung Kecamatan Lebong Sakti, sekitar 30 orang, selebihnya tersebar dibeberapa daerah di yang ada di Kabupaten Lebong (Dinas Pemberdayaan Masyarakat Desa dan Sosial Kabupaten Lebong, 2018). Berdasarkan pengamatan, sebagian waria di Kabupaten Lebong ada berusaha menampilkan jati dirinya sebagai seorang laki-laki (namun kelihatan kaku), dapat hidup berdampingan dengan masyarakat secara baik, punya keluarga (isteri), ada yang bekerja sebagai petani, salon dan rias pengantin bahkan ada yang berprofesi sebagai guru. Di sisi lain ada juga waria yang menampilkan jati dirinya sebagai perempuan, berdandan dan bertingkah laku layaknya perempuan. Kelompok ini biasanya kurang menyatu dengan masyarakat dan cenderung bersosialisasi dengan komunitasnya.

Secara umum pandangan sebagian masyarakat, waria sebagai perusak moral masyarakat, penghancur kehidupan keluarga, sebagai sampah masyarakat dan manusia tanpa harga diri, karena norma sosial dan agama tidak bisa menerima kehadiran waria (Faidah, 2014). Masyarakat Kabupaten Lebong memberikan dua stigma terhadap waria, yaitu: Pertama, stigma positif. Stigma positif diberikan kepada waria yang mampu menampilkan jati dirinya sebagai laki-laki (walaupun masih kaku) dan bisa bersosialisasi dengan masyarakat secara normal. Kedua, stigma negatif diberikan kepada waria yang menampilkan jati dirinya sebagai perempuan, tidak mampu bersosialisasi secara baik dalam kehidupan masyarakat dan cenderung bersosialisasi dengan komunitasnya. Bahkan Dinas Sosial Kabupaten Lebong mengkategorikan kelompok kedua ini sebagai warga yang rawan sosial. Oleh karena itu, waria kelompok kedua ini diberikan pembinaan dan bantuan oleh dinas terkait seperti memberikan keretampilan salon, menjahit, diberi bantuan modal dan sebagainya.

Waria rawan sosial, di samping perlu diberikan beberapa keretampilan, juga sangat penting diberikan bantuan untuk mengembalikan konsep dirinya menjadi konsep diri yang positif. Konsep diri pada dasarnya adalah perasaan atau pandangan terhadap diri sendiri. Perasaan atau pandangan itu timbul akibat dari perasaan, pikiran, penilaian dan pendapat baik diri sendiri maupun dari dari orang lain tentang dirinya yang meliputi karakteristiknya, potensinya maupun sikap dan perilaku yang dimilikinya. Konsep diri seseorang dipengaruhi oleh banyak faktor. Nuryanto menjelaskan, beberapa faktor yang mempengaruhi terbentuknya konsep diri seseorang, yaitu kondisi fisik, bahasa, umpan balik lingkungan, peran jenis dan pola asuh orang tua.

Konsep diri merupakan bagian terpenting pada setiap diri individu dalam bersikap dan bertingkah laku. Sikap dan tingkah laku seseorang pada dasarnya sangat ditentukan oleh perasaan dan cara pandang seseorang terhadap dirinya sendiri. Jika individu memiliki konsep diri yang positif, maka sikap dan perilakuknya akan cenderung positif, sebaliknya jika individu memiliki konsep diri negatif makan sikap dan perilakuknya akan cenderung negatif. Begitu juga halnya dengan waria, sikap dan perilakunya sangat ditentukan oleh konsep dirinya. Jika waria merasakan dan memandang dirinya sebagai seorang pria sejati maka akan cenderung berekspresi, berpenampilan dan diperlakukan sebagaimana laki-laki. Pada gilirannya dapat hidup normal layaknya sebagai laki-laki sesuai dengan norma dan agama, mampu menjalin hubungan sosial di masyarakat secara baik dan setigma negatif pada waria rawan sosial akan hilang dengan sendirinya, begitu juga sebaliknya.

Penelitian terkait dengan waria sudah banyak dilakukan diantaranya adalah penelitian yang dilakukan oleh Barmawi dan Miftahul Silmi, judul penelitian Identifikasi Penyebab Transgender pada Waria di Banda Aceh. Temuan penelitian menunjukkan bahwa faktor sosial dari keluarga, perbedaan pola asuh yang diterapkan dalam keluarga memberikan pengaruh yang cukup signifikan penyebab transgender waria di Banda Aceh (Barmawi \& Silmi, 2017). Mutimmatul Faidah dan Husni Abdullah, judul penelitian Religiusitas dan 
Konsep Diri Waria. Penelitian ini bertujuan untuk mengungkapkan tentang religiusitas yang mencakup keyakinan, pengetahuan agama, penghayatan dalam menjalankan agama, ketaatan dalam menjalankan ritual ibadah, serta dimensi sosial dan konsep diri waria. Penelitian ini juga berusaha mengungkap tentang konsep diri waria yang dikaitkan dengan takdir (Faidah, 2014), namun tanpa memberikan solusi untuk meningkatkan konsep diri positif waria.

Depilori dan Ivan Th. J. Weismann, judul penelitian Penyebab Krisis Identitas Waria. Penelitian ini berusaha menggali secara mendalam tentang faktor-faktor yang menyebabkan terjadinya krisis identitas waria. Terjadinya krisis identitas waria menurut penelitian ini disebabkan oleh kesalahan pola asuh orang tua (Depilori, 2014). Darmawati yang meneliti tentang efektifitas Tehnik Konseling Eklektik untuk mengatasi kebiasaan merokok yang terjadi pada siswa. Penelitian ini menggunakan angket dan wawancara sebagai instrument penelitian dengan 6 siswa sebagai sampel penelitiannya. Metode penelitian yang digunakan adalah kualitatif. Hasil penelitian ini menunjukkan bahwa teknik konseling yang digunakan hanya mampu menurunkan kebiasaan merokok. Dalam artian bahwa belum sepenuhnya mampu menghilangkan kebiasaan merokok bagi siswa dan subyeknya bukan waria melainkan siswa.

Isnaeni dan Slamet juga melakukan penelitian tentang konseling Islam kepada waria. Penelitian tersebut menggunakan metode lapangan di pondok pesantren waria senin-kamis di Yogyakarta. Instrumen penelitian ini adalah lembar observasi, wawancara dan dokumentasi. Metode yang diterapkan dalam penelitian ini memiliki kekurangan seperti dalam hal mengalihkan perasaan hati yang terdalam. Tahap ini lama kelamaan menimbulkan kebosanan karena zikir dan istighfar yang dilakukan menimbulkan kebosanan dan monoton. Kedua, membutuhkan biaya yang cukup tinggi terutama dalam tahapan menumbuhkan kesadaran atas kematian. Ketiga kekurangan metode ini adalah para waria kurang mampu menanamkan rasa percaya diri. Keempat, kesulitan dalam menumbuhkan rasa kasih sayang.

Berdasarkan penelitian terdahulu, dapat dikatakan bahwa penelitian terdahulu sudah ada yang menggunakan tehnik konseling eklektik namun ditujukan untuk mengatasi masalah kebiasaan merokok siswa, bukan untuk waria. Kebanyakan peneliti sebelumnya menggunakan tehnik konseling Islam pada waria, namun hasilnya tidak memuaskan karena disebabkan oleh beberapa hal seperti kebosanan, biaya dan waktu. Selain itu, para peneliti sebelumnya hanya membahas tentang faktor yang mempengaruhi pria tersebut menjadi waria. Dengan adanya informasi mengenai penelitian terdahulu dan berdasarkan hasil wawancara dan observasi yang telah dilakukan, penelitian ini menekankan pada pemberian bantuan kepada waria rawan sosial untuk mengembalikan konsep dirinya menjadi konsep diri yang positif. Karena konsep diri positif sebagai penentu sikap dan perilaku dalam kehidupan sehari-hari setiap individu termasuk waria. Salah satu cara yang diyakini dapat mengembalikan konsep diri waria adalah dengan memberikan layanan konseling eklektik Islami. Konseling eklektik pada dasarnya adalah konseling yang didasarkan pada berbagai konsep dan tidak berorientasi pada satu teori secara ekslusif (Prayitno, 2009). Konselor menggunakan berbagai sumber yang tersedia guna membantu mengentaskan masalah klien termasuk menggunakan pendekatan Islam.

Penelitian ini bertujuan untuk; 1) mengungkapkan konsep diri waria yang ada di Desa Ujung Tangung Kecamatan Lebong Sakti Kabupaten Lebong provinsi Bengkulu. 2) memberikan bantuan pelayanan konseling eklektik Islami untuk mengubah konsep diri Waria di Desa Ujung Tangung Kecamatan Lebong Sakti Kabupaten Lebong provinsi Bengkulu.3) mengetahui tingkat keefektifan konseling eklektik Islami untuk mengubah konsep diri waria di Desa Ujung Tangung Kecamatan Lebong Sakti Kabupaten Lebong.

\section{Metode Penelitian}


Jenis penelitian yang digunakan adalah Participatory Action Resarch (PAR). Kemmis dan McTaggert (dalam Don K. Marut) mengatakan, Participatory Action Resarch (PAR) merupakan penelitian yang berbentuk self reflective dilaksanakan secara kolektif oleh partisipan dalam situasi sosial dalam rangka untuk meningkatkan rasionalitas, pemahaman dan perubahan perilaku sosial (Don K Marut, 2004). Menurut Yoland Wadworth, Participatory Action Research (PAR) pada dasarnya adalah penelitian yang melibatkan semua pihak yang relevan, baik dalam merumuskan masalah maupun dalam melakukan tindakan untuk mengentaskan masalah tersebut. Hal tersebut dilakukan secara kritis dengan berbagai pendekatan baik historis, politik, budaya, ekonomi, geografis dan konteks lain yang memahaminya (Reason \& Bradbury, 2001). Dengan kata lain, Participatory Action Research (PAR), dalam pelaksanaannya melibatkan secara aktif semua stakeholder yang relevan dalam merumuskan masalah, mengkaji dan merencanakan dan melakukan tindakan dalam rangka melakukan perubahan dan perbaikan ke arah yang lebih baik.

Dalam penelitian ini, peneliti tidak menjadikan waria sebagai objek penelitian, tetapi menjadikan waria sebagai subjek penelitian. Dengan pendekatan ini diharapkan waria dapat memahami, menginginkan dan memecahkan problematika yang dialaminya. Posisi peneliti hanya sebagai fasilitator untuk membantu merumuskan dan mengatur strategi dalam mengentaskan masalah dengan melibatkan waria dan masyarakat sekitarnya.

Langkah-langkah pelaksanaan kegiatan yang peneliti gunakan adalah sebagai berikut; Pertama, perencanaan, perencanaan ini diawali dengan mengkaji, memahami dan menganalisis problematika waria yang ada di desa Ujung Tanjung Kecamatan Lebong Sakti Kabupaten Lebong Provinsi Bengkulu. Kemudian disusun rencana strategi dan metode yang digunakan untuk mengentaskan problematika yang dialami oleh waria khusunya terkait dengan konsep diri. Kedua, tindakan. Tindakan yang dilakukan untuk mengatasi problematika yang dihadapi oleh waria terkait dengan konsep diri adalah dengan melakukan konseling eklektik Islami. Ketiga, penilaian. Penilaian yang digunakan adalah penilaian lisan. Artinya beberapa saat sebelum kegiatan konseling berakhir atau beberapa hari setelah layanan konseling selesai dilakukan, peneliti mengajukan beberapa pertanyaan kepada klien. Pertanyaan tersebut mencakup tiga aspek, yaitu understanding yaitu pamahaman baru yang diperoleh waria dari proses konseling. Comfort, yatu perasaan yang dirasakan oleh waria selama atau setelah mengikuti proses konseling. Attion, yaitu rencana atau kegiatan apa yang akan dilakukan setelah mengikuti proses konseling. Kegiatan itu tentunya terkait dengan upaya pengentasan problematika yang dialami oleh waria berkaitan dengan konsep dirinya.

Hasil pengamatan atau penilaian tersebut kemudian dianalisis dan dilakukan kegiatan tindak lanjut. Kegiatan tindak lanjut bertujuan untuk mengurangi berbagai keluhan yang ditemui dan guna untuk mencapai target-target yang belum tercapai.

\section{Hasil dan Pembahasan}

\section{Gambar Konsep Diri Waria di Desa Ujung Tanjung}

Berdasarkan wawancara yang peneliti lakukan dengan waria yang ada di Desa Ujung Tanjung Kecamatan Lebong Sakti Kabupaten Lebong, dapat diketahui bahwa konsep diri waria terhadap dirinya sendiri secara garis besar dapat dikelompokkan menjadi dua, yaitu : Pertama, waria yang memandang atau memahami dirinya sebagai seorang perempuan dan itu sudah merupakan takdir. Mereka tidak bisa mendustai perasaannya, dan akhirnya penampilan, sikap tingkah lakunya seperti apa yang mereka rasakan, yaitu seperti perempuan. Hal ini seperti diungkapkan oleh "M", menurut "M" dirinya adalah seorang perempuan bahkan sejak usia SD ia lebih senang bergaul dengan teman perempuan (M, 2018). Senada dengan itu, "Y" juga mengatakan bahwa dirinya adalah peremupan, oleh karena itu ia harus tampil layaknya perempuan pada umumnya, lebih nyaman berteman dan bergaul dengan sesama waria atau dengan perempuan (Y, 2018). 
Lebih lanjut "Y" menjelaskan, ia menjelaskan sejak kecil sudah merasakan dirinya perempuan, lebih senang pakaian perempuan, bermain dengan perempuan dan sebagainya (Y, 2018). Adanya kecenderungan seperti itu, orang tuanya tidak marah dan tidak melarangnya. Berbeda dengan "T", menurutnya memang sejak kecil lebih senang berpenampilan seperti perempuan, walaupun orang tua melarangnya, bahkan orang tua sering marah dan pernah menghukumya, namun dorongan yang ada dari dalam dirinya tidak dapat dihilangkan ( $\mathrm{T}$, 2018). Walaupun lebih senang bermain dengan perempuan, dalam dirinya lebih tertarik menjalin hubungan dengan laki-laki T, 2018).

Kedua, waria yang memandang dirinya sebagai seorang laki-laki, dan sudah berupaya tampil sebagaimana layaknya laki. Namun secara reflek muncul sikap dan perilaku seperti perempuan. "S" mengatakan dirinya adalah laki-laki, makanya ia berpakaian seperti laki-laki, walaupun begitu lebih lanjut ia menjelaskan menurut orang penampilannya seperti perempuan (S, 2018).

Hasil wawancara juga menunjukkan bahwa, pandangan waria tentang lingkungan sekitar terhadap dirinya secara umum adalah sebagai berikut, Pertama, masyarakat memandangnya sebagai seorang peremuan $(\mathrm{H}, 2018)$. Kedua, masyarakat lebih senang kalau waria tampil seperti perempuan (R, 2018). Ketiga, masyarakat memandang sebelah mata terhadap waria, baik dari segi penampilan maupun dari segi kemampuan K, 2018). Waria mempunyai beberapa harapan terkait penampilannya dan profesinya. Dari wawancara yang peneliti lakukan dengan waria terkait harapan-harapan yang diinginkan oleh waria secara umum dalat dikelompokan menjadi dua, yaitu: Pertama, waria mengharapkan agar masyarakat tidak memandang dirinya sebalah mata. Mereka menginginkan penampilannya dihargai, profesinya didukung dan diberikan kesempatan seluas-luasnya untuk mengekspresikan dirinya. Kedua, waria juga mengharapkan agar masyarakat tidak mengucilkannya. Ketiga, suatu saat nanti mudah-mudah dapat hidayah dan petujuk dari tuhan (Yc, 2018).

\section{Pelaksanan Konseling Eklektik Islami}

Berdasarkan hasil pengumpulan data terkait dengan waria dan problematikanya sebagaimana diuraikan di atas, peneliti berkoordinasi dengan Dinas Pemberdayaan Masyarakat Desa dan Sosial, Kapala Desa Ujung Tanjung 1, 2, 3 dan berdiskusi dengan waria untuk melakukan upaya dalam membantu mengentaskan problematika yang dialami oleh waria. Setelah di koordinasikan dengan Kepala Dinas Pemberdayaan Masyarakat desa, Kepala Bidang Soial, Kepala Desa dan diskusi dengan waria yang manjadi subjek penelitian, maka disepakati bahwa untuk membantu mengentaskan problematika waria khususnya terkait dengan konsep diri akan dilakukan konseling eklektik Islami berbasis kearifan lokal.

Gambaran pelaksanaan kegiatan konseling tersebut secara garis besar terdiri dari lima tahap (Wingkel, 2000), yaitu :

1. Tahap Pembukaan

Pada tahap pembukaan ini, ada beberapa rangkaian kegiatan yang dilakukan, yaitu :

a. Diawali dengan mengucapkan salam dan dibuka dengan membaca basmalah

b. Membaca doa

c. Perkenalan

d. Menjelaskan tentang hakekat konseling, tujuan, tata cara pelaksanaan dan asas-asas yang harus dipegang teguh baik oleh klien maupun tim peneliti. Asas-asas yang penting untuk disampaikan adalah asas kerahasiaan, yaitu: Pertama, asas dimana semua data, informasi dan keterangan diperoleh selama proses konseling tidak akan disampaikan atau disebarluaskan ke pihak lain tanpa sepengetahuan atau seizin yang bersangkutan. Kedua, asas keterbukaan, yaitu asas dimana klien harus secara terbuka mengemukakan apa yang dirasakan, dialami, dan dipikirkan terutama terkait dengan 
problematika yang dibicarakan selama proses konseling. Ketiga, asas kekinian, yaitu asas dimana selama proses konseling yang dibicarakan dalam masalah atau problematika yang sedang dialami, bukan masa lalu dan bukan masa akan datang. Keempat, asas kegiatan, yaitu asas dimana tim peneliti bertindak sebagai konselor dan waria sebagai klien harus sama-sama bekerja sama dan melakukan beberapa rangkaian kegiatan terkait dengan pelaksanaan konseling.

2. Tahap Penjajakan Masalah

Pada tahap penjajakan ini, tim peneliti selaku konselor melakukan wawancara konseling dengan waria selaku klien. Dalam wawancara konseling tersebut, peneliti selaku konselor menjajaki problematika yang dihadapi oleh waria terkait dengan konsep dirinya. Hasil penjajakan masalah terkait dengan konsep diri waria tersebut antara yang satu dengan lainnya memiliki kemiripan. Secara garis besar problematika waria terkait dengan konsep dirinya dapat dikelompokkan menjadi tiga, yaitu:

a. Waria yang mempersepsikan dirinya sebagai perempuan, kemudian menampilkan apa yang dipersepsikan tersebut ke dalam sikap dan perilakunya dalam kehidupan sehari, baik cara berpakaian, cara berdandan, berbicara dan sebagainya.

b. Waria yang menyadari bahwa dirinya adalah laki-laki, namun tidak bisa menolak dorongan dari dalam diri. Dorongan tersebut muncul semakin kuat disebabkan karena menuntutnya teman-temannya mengatakan dirinya sebagai perempuan. Akibatnya mereka tetap bersikap dan bertingkah seperti perempuan serta bergaul cenderung dengan sesama waria.

c. Waria yang menyadari dirinya laki-kali dan mampu menampilkan diri seperti lakilaki pada umumnya terutama cara berpakaian dan berdandan. Namun cara berbicara dan gerakannya masih seperti perempuan.

3. Tahap Penggalian Masalah

Pada tahap penggalian masalah ini, tim peneliti menggali secara mendalam terkait problematika waria sebagaimana dikemukakan pada tahap penjajakan. Setelah dilakukan pendalaman, ternyata pada umumnya kecenderungan untuk tampil seperti perempuan sudah ada sejak kecil, rata-rata mereka mangatakan sejak SD kelas dan SMP. Tanggapan orang tua terkait penampilannya tersebut, dapat dikelompokkan menjadi dua, yaitu: Pertama, ada orang tua yang menolak keras sikap dan penampilannya tersebut. Bahkan ada yang sampai menghukum, seperti memukul, mengurung di kamar, membuang barang dan aksesoris yang dimiliki, serta ada juga yang sampai memotong rambutnya sampai habis. Namun dorongan yang ada di dalam dirinya tetap ada dan tidak mau hilang sampai sekarang. Kedua, ada orang tua yang pada awalnya marah, namun setelah berupaya untuk melarang berpenampilan seperti wanita tidak berhasil, akhirnya mereka membiarkannya.

Di sisi lain ada juga waria yang mengatakan bahwa pada dasarnya mereka menyadari dirinya sebagai laki-laki, namun pada akhirnya ia berpenampilan dan berperilaku seperti perempuan. Hal ini disebabkan karena adanya dorongan dari dalam dirinya dan adanya ketidaknyamanan tampil seperti laki-laki. Ketidaknyamanan tersebut dikarenakan adanya pandangan orang disekelilingnya, seperti teman, guru bahkan masyarakat sekitar yang mengatakan dirinya sebagai "bencong". Mereka merasa resah dan tidak nyaman perpakaian dan berteman dengan laki-laki, bahkan mereka lebih nyaman berpakaian dan berpenampilan seperti perempuan. Pada akhirnya mereka berteman hanya dengan sesama waria sampai sekarang.

Di lihat latar belakang keluargaya, dari 20 orang waria yang diwawancarai melalui wawancara konseling mangatakan bahwa 9 orang diantaranya menyatakan mereka berasal dari keluarga yang kurang harmonis. Di masa kecil mereka sering menyaksikan pertengkaran orang tua, bahkan ada yang mengatakan sewaktu kecil pernah menyaksikan 
ayahnya memukul ibunya dan pada akhirnya orang tuanya bercerai dan ia besarkan oleh ibunya.

Berkaitan dengan harapannya di masa depan, ada yang mereka ingin hidup normal sebagaimana laki-laki pada umunya. Namun sampai saat ini kebanyakan mereka menyatakan belum mampu melakukannya. Menurutnya, penyebabnya adalah, di samping karena adanya dorongan dari dalam dirinya, juga mereka merasa kalau berubah penampilan mereka kurang diterima dilingkungan masyarakat, dan akan susah mencari pekerjaan. Selama ini masyarakat sudah banyak mengenalnya sebagai waria. Bahkan mereka ada yang punya langganan salon, rias pengantin dan sebagai penyanyi orgen tunggal. Ada juga yang mengatakan, ingin berubah namuna kecenderungan untuk tampil seperti perempuan sering muncul dan muncul lagi.

4. Tahap Pengentasan Masalah

Tahap pengentasan masalah merupakan tahap dimana tim peneliti sebagai konselor menawarkan solusi guna mengentaskan problematika yang dialami oleh waria terkait dengan konsep diri. Konsep diri pada dasarnya adalah persepsi atau pemahaman seseorang terkait dengan dirinya sendiri. Berdasar penggalian masalah sebagaimana dikemukakan di atas, dapat dipahami bahwa konsep diri waria yang menjadi subjek penelitian adalah sebagai berikut:

a. Sesungguhnya waria yang menjadi subjek penelitian ini adalah laki-laki, namun mereka memahami dan pempersepsikan dirinya sebagai perempuan. Hal ini disebabkan karena adanya dorongan dari dalam dirinya dan atau karena adanya pengaruh lingkungan. Akibatnya mereka berpakaian, bercicara, bersikap dan bertingkah laku seperti perempuan.

b. Waria yang menjadi subjek penelitian sungguhnya ada yang punya keinginan untuk merubah penampilannya, namun sampai saat ini belum bisa. Ada juga waria belum berkeinginan untuk merubah penampilannya.

Sebagaimana dikemukakan di atas, konsep diri waria merupakan pemahaman atau persepsi waria tentang dirinya sendiri. Oleh karena adanya kesalah persepsi atau kesalahan pemahaman waria tentang dirinya, maka langkah awal yang peneliti lakukan, adalah merubah pemahaman atau persepsi waria terhadap dirinya sendiri. Teknik yang peneliti gunakan dalam merubah pemahaman atau persepsi waria terhadap dirinya sendiri adalah teknik CBI, yaitu cognitive behaviour Islami. Maksudnya memberikan pemahaman kepada waria tentang cara laki-laki dan perepuan berpakaian, bersikap dan bertingkah laku dalam persfektif Islam.

Pada tahap ini tim peneliti memberikan pemahaman kepada waria, bahwa dalam pandangan Islam laki-laki harus bersikap dan berperilaku sebagaimana layaknya laki. Begitu juga halnya dengan perempuan, harus bersikap dan berpenampilan sebagaimana layaknya perempuan. Hal ini sesuai dengan sabda Rasulullah SAW yang diriwayatkan oleh Ibnu Abbas yang artinya: "Rasulullah SAW melaknat laki-laki yang menyerupai wanita dan wanita yang menyerupai laki-laki." Dalam hadis lain yang diriwayatkan oleh Abu Hurairah yang artinya "Rasulullah SAW melaknat laki-laki yang memakai pakaian perempuan dan perempuan yang memakai pakaian laki-laki".

Dalam bagian ini juga dijelaskan makna menyerupai laki-laki atau menyerupai perempuan, yaitu meyerupai dari cara berpakaian, berbicara, bersikap dan bertingkah laku. Maksud "melaknat" adalah menolak dan menjauhkan dari rahmad Allah SWT, mulai dari ampunan, rizki, hidayah, taufik, rizki dan sebagainya. Oleh karena laki-laki harus tampil, bersikap dan berperilaku sebagaimana layaknya laki-laki, begitu juga perempuan harus tampil sesuai dengan jati dirinya. Terlebih lagi sampai ada lelaki yang menyukai sesama lelaki (atau lebih jauh dari itu) maka akan dilaknat oleh Allah SWT. 
Hal ini sebagaimana dialami oleh umat Nabi Luth yang dilaknat oleh Alla SWT karena perilakunya menyukai sesama jenis.

5. Tahap Pengakhiran

Tahap pengakhiran merupakan tahap dimana proses konseling akan segera diakhiri. Pada tahap ini ada beberapa hal yang dilakukan:

a. Memberitahu kepada klien bahwa konseling akan segera diakhiri

b. Melakukan penilaian segera, yaitu menanyakan tentang pemahamannya, perasaannya dan rencana yang akan dilakukan akan datang. Secara umum dapat dikatakan bahwa setelah mengikuti proses konseling klien memperoleh pemahamnpemahaman baru. Pemahaman-pemahaman baru tersebut diantaranya adalah dalam pandang Islam laki-laki tidak boleh berpenampilan seperti perempuan, begitu juga sebaliknya. Klien merasa senang setelah mengikuti proses konseling, sebab dengan adanya konseling ini apa yang meraka rasakan selama ini dapat diungkapkan dan dicarikan solusinya. Mereka mengatakan, rupanya ada juga orang mau memperhatikannya. Terkait dengan rencana dimasa akan datang, dapat dikelompokkan menjadi dua, yaitu: Petama, ada waria yang berkeinginan untuk merubah cara penampilan, sikap dan perilakunya. Mereka sudah menyadari apa yang ditampilkan selama ini bertentangan dengan nilai-nilai agama. Kedua, ada waria yang belum berkeinginan untuk merubah cara berpakaian, bersikap dan berperilaku. Hal ini disebabkan karena mereka takut tetap akan kurang diterima di lingkungannya, takut kehilangan pelanggannya (salon, rias pengantin dan penyanyi organ tunggal).

c. Memberikan komitmen, yaitu memberikan penegasan kepada waria keinginan untuk berubah itu akan dilaksanakan.

d. Di tutup dengan membaca doa dan diakhiri dengan salam

\section{Tingkat Efektivitas Konseling Eklektik Islami untuk Mengubah Konsep Diri Waria}

Setelah beberapa hari proses konseling dilakukan, peneliti melakukan evaluasi terhadap kegiatan konseling yang telah dilaksanakan. Hasil evaluasi menunjukkan bahwa dari 18 orang waria yang mengikuti proses konseling, 7 orang masih tetap memahami dirinya sebagai perempuan dan harus tampil sebagai mana layaknya perempuan. 10 orang sadar bahwa dirinya adalah laki-laki dan penampilanya seharusnya seperti laki-laki namun belum tahu kapan akan merubah penampilannya. Ada 1 orang yang berinisal "H" sudah berkomitmen ingin benar-benar merubah penampilannya.

Dari hasil evaluasi secara umum dapat dikatakan bahwa sekitar 55\% konseling eklektik Islami dapat memberikan pemahaman bahwa dirinya adalah laki-laki. Namun pemahaman tersebut belum diiringi dengan keinginan untuk merubah penampilannya, dan hanya 1 orang (1\%) berkomitmen ingin merubah penampilannya. Oleh karena itu perlu adanya dukungan dari semua pihak dalam rangka untuk memberikan pemahaman tentang konsep diri waria sehingga muncul keinginan untuk merubah penampilannya.

\section{Simpulan dan Saran}

Dari uraian di atas dapat disimpulkan bahwa: Waria dalam memahami konsep dirinya dapat dikelompokkan menjadi dua, yaitu; Pertama, waria yang memandang dirinya sebagai seorang perempuan dan itu sudah merupakan takdir. Kedua, waria yang memandang dirinya sebagai seorang laki-laki, dan sudah berupaya tampil sebagaimana layaknya laki. Namun secara reflek muncul sikap dan perilaku seperti perempuan. Di sisi lain, waria memandang bahwa masyarakat memandang dirinya sebagai seorang peremuan, harus tampil seperti perempuan dan beranggapan masyarakat memandang sebelah mata terhadap dirinya. Dari 20 
orang waria yang mengikuti proses konseling, 8 orang masih tetap memahami dirinya sebagai perempuan dan harus tampil sebagaimana layaknya perempuan. 11 orang sadar bahwa dirinya adalah laki-laki dan penampilanya seharusnya seperti laki-laki namun belum tahu kapan akan merubah penampilannya. 1 orang bertekad ingin benar-benar ingin merubah penampilannya.

\section{Daftar Pustaka}

Barmawi, B., \& Silmi, M. (2017). Identifikasi Penyebab Transgender pada Waria di Banda Aceh. Psikoislamedia: Jurnal Psikologi, 1(2).

Faidah, M. (2014). Religiusitas dan Konsep Diri Kaum Waria. Jurnal Studi Gender Indonesia, 4(1).

Koeswinarno. (2005). Hidup sebagai Waria. Yogyakarta: LKis.

Prayitno. (2009). Konseling Pancawaskita: Kerangka Konseling Eklektik. Padang: UNP Press.

Reason, P., \& Bradbury, H. (2001). Handbook of action research: Participative inquiry and practice. Sage.

Wingkel, W. S. (2000). Bimbingan dan Konseling dalam institusi Pendidikan. Jakarta: Gramedia. 
